\title{
Analgesic comparison between perineural and intravenous dexamethasone for shoulder arthroscopy: a meta-analysis of randomized controlled trials
}

\author{
Liangku Huang ${ }^{1 \dagger}$, Peng $\mathrm{Li}^{1 \dagger}$, Liang Zhang ${ }^{3}$, Guangming Kang ${ }^{1}$, Haizhen Zhou ${ }^{2}$ and Zandong Zha ${ }^{3 *}$
}

\begin{abstract}
Introduction: The analgesic comparison between perineural and intravenous dexamethasone on interscalene block for pain management after shoulder arthroscopy remains controversial. We conduct this meta-analysis to explore the influence of perineural versus intravenous dexamethasone on interscalene block for pain control after shoulder arthroscopy.

Methods: We have searched PubMed, Embase, Web of science, EBSCO and Cochrane library databases through April 2021 and included randomized controlled trials (RCTs) assessing the effect of perineural and intravenous dexamethasone on interscalene block in patients with shoulder arthroscopy.

Results: Five RCTs were included in the meta-analysis. Overall, compared with intravenous dexamethasone for shoulder arthroscopy, perineural dexamethasone led to similar block duration ( $\mathrm{SMD}=0.12 ; 95 \% \mathrm{Cl}-0.12$ to $0.35 ; P=0.33)$, pain scores at $12 \mathrm{~h}(\mathrm{SMD}=-0.67 ; 95 \% \mathrm{Cl}-1.48$ to $0.15 ; P=0.11)$, pain scores at $24 \mathrm{~h}(\mathrm{SMD}=-0.33 ; 95 \% \mathrm{Cl}-0.79$ to $0.14 ; P=0.17)$, opioid consumption $(\mathrm{SMD}=0.01 ; 95 \% \mathrm{Cl}-0.18$ to $0.19 ; P=0.95)$ and incidence of nausea/vomiting $(\mathrm{OR}=0.74 ; 95 \% \mathrm{Cl} 0.38-1.44 ; P=0.38)$.
\end{abstract}

Conclusions: Perineural and intravenous dexamethasone demonstrated comparable pain relief after shoulder arthroscopy.

Keywords: Perineural dexamethasone, Intravenous dexamethasone, Shoulder arthroscopy, Pain management, Randomized controlled trials

\section{Introduction}

Arthroscopy has been widely accepted to diagnose and treat shoulder diseases [1-3]. However, significant postoperative pain is the main concern after this surgery and effective analgesia is required for this day-case surgery

\footnotetext{
*Correspondence: zhaozandong@163.com

${ }^{\dagger}$ Liangku Huang and Peng Li contributed equally to this study

${ }^{3}$ Sports Medicine Center, Xi'an Honghui Hospital, Xi'an Jiaotong

University Health Science Center, No. 555 Youyidong Street, Beilin District,

Xi'an 710054, Shaanxi, China

Full list of author information is available at the end of the article
}

[3-5]. Interscalene brachial plexus block (ISB) is the standard analgesia after shoulder surgery with the features of superior analgesia and reduced opioid consumption [6-8]. ISB is limited by short analgesic maintenance for several hours, and especially moderate to severe pain of this surgery requires opioid supplementation [9].

The increase in the dose of local anesthetic is used to prolong ISB, but has the limitation of narrow therapeutic window and volume/concentration. Volumes of $10 \mathrm{ml}$ or greater injected into the interscalene groove can increase the risk of ipsilateral hemi-diaphragmatic paresis [10]. 
Several anesthetics have been developed to prolong ISB. In particular, dexamethasone used by perineural approach showed the potential in prolonging the duration of peripheral nerve blocks when in conjunction with local anesthetics [11].

Recently, several studies have compared the analgesic efficacy between perineural with intravenous dexamethasone for the pain management after shoulder arthroscopy, but the results are conflicting [10, 12, 13]. With accumulating evidence, we therefore perform this metaanalysis of RCTs to compare perineural with intravenous dexamethasone for shoulder arthroscopy.

\section{Materials and methods}

Ethical approval and patient consent were not required because this was a meta-analysis of previously published studies. We conducted this meta-analysis in adherence to PRISMA (Preferred Reporting Items for Systematic Reviews and Meta-Analyses) [14, 15].

\section{Search strategy and study selection}

Two investigators have independently searched the following databases (inception to April 2021): PubMed, Embase, Web of science, EBSCO and Cochrane library databases. The electronic search strategy was conducted using the following keywords: "dexamethasone" AND "interscalene block" AND "shoulder arthroscopy." We also checked the reference lists of the screened full-text studies to identify other potentially eligible trials.

The inclusive selection criteria were as follows: (i) patients underwent shoulder arthroscopy; (ii) intervention treatments were perineural versus intravenous dexamethasone as the adjunctive therapy to interscalene block; (iii) study design was RCT.

\section{Data extraction and outcome measures}

We extracted the following information: author, number of patients, age, female, body weight, American Society of Anesthesiologists (ASA) physical status and detail methods in each group etc. Data were extracted independently by two investigators, and discrepancies were resolved by consensus. We also contacted the corresponding author to obtain the data when necessary. The primary outcome was block duration. Secondary outcomes included pain scores at $12 \mathrm{~h}$, pain scores at $24 \mathrm{~h}$, opioid consumption, and the incidence of nausea/vomiting.

\section{Quality assessment in individual studies}

Methodological quality of the included studies was independently evaluated using the modified Jadad scale [16]. There were three items for Jadad scale: randomization (0-2 points), blinding ( $0-2$ points) and dropouts and withdrawals $(0-1$ points). The score of Jadad Scale varied from 0 to 5 points. An article with Jadad score $\leq 2$ was considered to be of low quality, while Jadad score $\geq 3$ suggested high quality [17].

\section{Statistical analysis}

We estimated the standard mean difference (SMD) with 95\% confidence interval (CI) for continuous outcomes (block duration, pain scores at $12 \mathrm{~h}$, pain scores at $24 \mathrm{~h}$ and opioid consumption) and odd ratios (ORs) with 95\% CIs for dichotomous outcomes (nausea/vomiting). The random-effects model was used regardless of heterogeneity. Heterogeneity was reported using the $\mathrm{I}^{2}$ statistic, and $\mathrm{I}^{2}>50 \%$ indicated significant heterogeneity $[15$, 18]. We searched for potential sources of heterogeneity via omitting one study in turn for the meta-analysis or performing subgroup analysis. All statistical analyses were performed using Review Manager version 5.3 (The Cochrane Collaboration, Software Update, Oxford, UK).

\section{Results}

Literature search, study characteristics and quality assessment

Figure 1 demonstrates the detailed flowchart of the search and selection results. Initially, 78 potentially relevant articles were identified and five RCTs were finally included in the meta-analysis $[10,12,13,19,20]$. The baseline characteristics of five eligible RCTs in the metaanalysis are summarized in Table 1 . The five studies were published between 2016 and 2020, and total sample size was 585 .

The doses of perineural or intravenous dexamethasone ranged from 1 to $5 \mathrm{mg}$, and the concentrations of perineural dexamethasone varied from $0.1333 \mathrm{mg} / \mathrm{ml}$ to $1 \mathrm{mg} / \mathrm{ml}$. Among the five studies included here, three studies reported block duration $[10,12,13]$, three studies reported pain scores at $12 \mathrm{~h}[10,19,20]$, four studies reported pain scores at $24 \mathrm{~h}[10,12,19,20]$, three studies reported opioid consumption $[10,12,13]$, and three studies reported nausea/vomiting [10, 19, 20]. Jadad scores of the five included studies varied from 3 to 5 , and all five studies had high quality according to quality assessment.

\section{Primary outcome: block duration}

These outcome data were analyzed with the randomeffects model, and compared to intravenous dexamethasone for shoulder arthroscopy, perineural dexamethasone resulted in comparable duration of sufficient analgesia, as evidenced by similar block duration $(\mathrm{SMD}=0.12$; $95 \% \mathrm{CI}$ -0.12 to $0.35 ; P=0.33)$ with low heterogeneity among the studies $\left(\mathrm{I}^{2}=37 \%\right.$, heterogeneity $P=0.33$ ) (Fig. 2). 


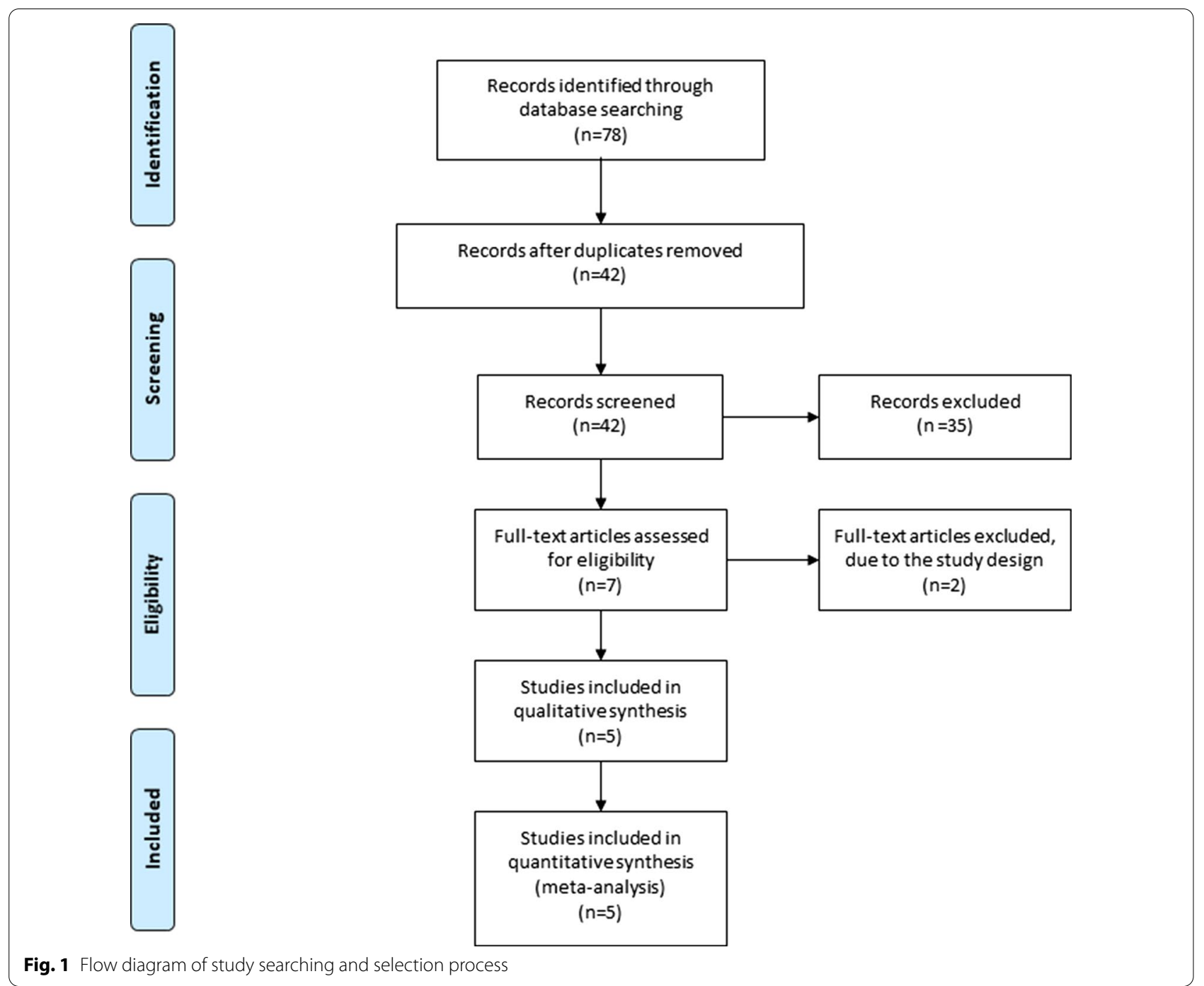

\section{Sensitivity analysis}

Low heterogeneity was observed among the included studies for the primary outcome, so we did not perform sensitivity analysis via omitting one study in turn to detect the heterogeneity.

\section{Secondary outcomes}

In comparison with intravenous dexamethasone for shoulder arthroscopy, perineural dexamethasone exhibited comparable control of pain intensity shown by pain scores at $12 \mathrm{~h}(\mathrm{SMD}=-0.67 ; 95 \% \mathrm{CI}-1.48$ to 0.15 ; $P=0.11$; Fig. 3$)$ and $24 \mathrm{~h}(\mathrm{SMD}=-0.33$; $95 \% \mathrm{CI}-0.79$ to $0.14 ; P=0.17$; Fig. 4 ). In addition, these two approaches of dexamethasone resulted in similar opioid consumption $(\mathrm{SMD}=0.01 ; 95 \% \mathrm{CI}-0.18$ to $0.19 ; P=0.95$; Fig. 5 ) and the incidence of nausea/vomiting $(\mathrm{OR}=0.74 ; 95 \% \mathrm{CI}$ $0.38-$ c1.44; $P=0.38$; Fig. 6 ).

\section{Discussion}

Serious pain after shoulder arthroscopy commonly occurs and mainly results from the insertion of arthroscopic instruments into the joint, soft tissue dissection and distention [21-25]. Patients' early mobilization and rehabilitation is significantly affected by this postoperative pain [26-28]. Numerous techniques have been studied, and ISB is widely accepted as the most effective analgesic technique for this surgery [3, 29-31]. Furthermore, supplementation with dexamethasone revealed a significant role in increasing the duration and analgesic efficacy of ISB for shoulder arthroscopy $[13,19]$.

Previous study comparing perineural and systemic dexamethasone showed that both routes were associated with prolonged and similar block duration [32-34]. In order to compare perineural with intravenous dexamethasone supplementation for ISB in patients with shoulder 


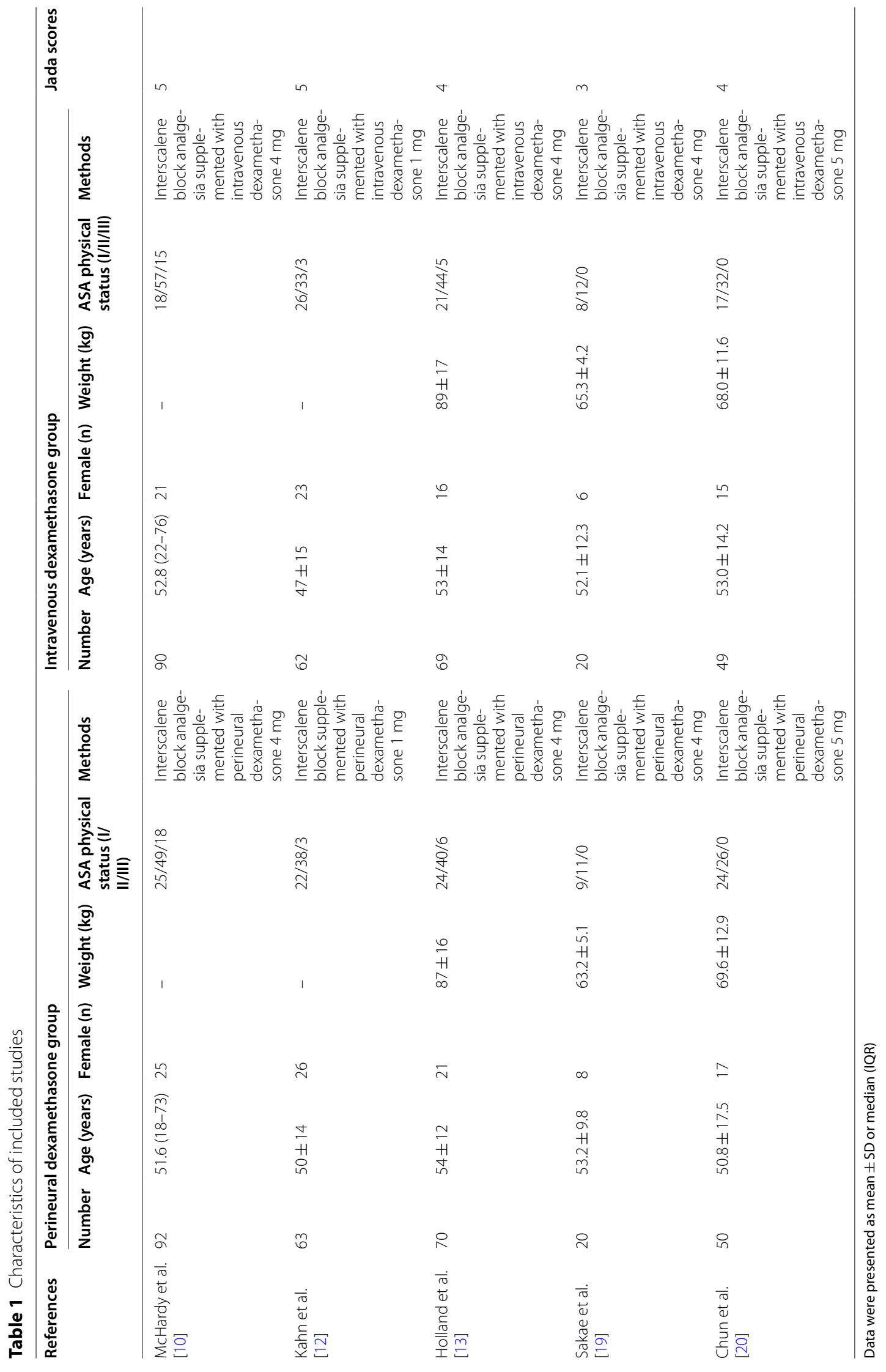




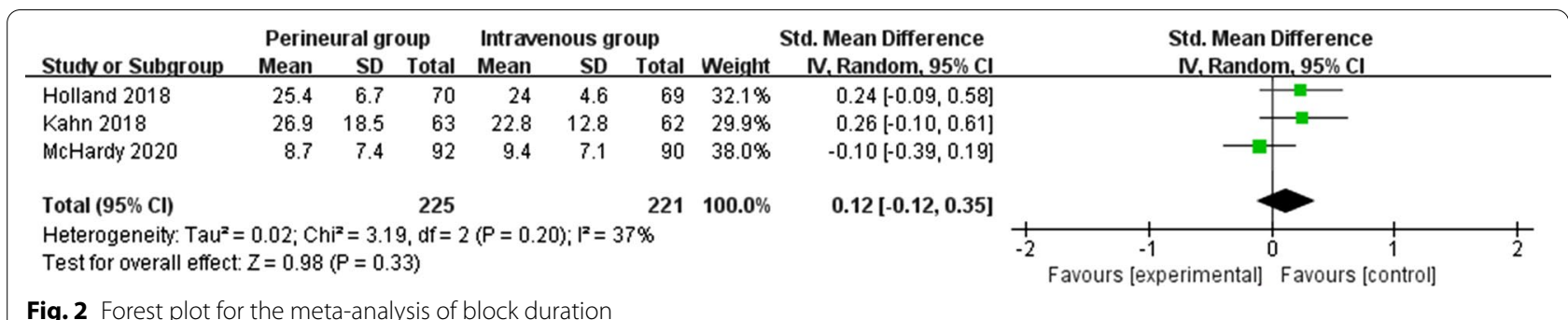

Fig. 2 Forest plot for the meta-analysis of block duration

\begin{tabular}{|c|c|c|c|c|c|c|c|c|c|c|c|}
\hline \multirow[b]{2}{*}{ Studv or Subgroup } & \multicolumn{3}{|c|}{ Perineural group } & \multicolumn{3}{|c|}{ Intravenous group } & & \multirow{2}{*}{$\begin{array}{l}\text { Std. Mean Difference } \\
\text { IV. Random, } 95 \% \mathrm{Cl}\end{array}$} & \multirow{2}{*}{\multicolumn{3}{|c|}{$\begin{array}{c}\text { Std. Mean Difference } \\
\text { N. Random. } 95 \% \mathrm{Cl}\end{array}$}} \\
\hline & Mean & SD & Total & Mean & SD & Total & Weight & & & & \\
\hline Chun 2016 & 2 & 0.75 & 50 & 3 & 1 & 49 & $34.0 \%$ & $-1.12[-1.55,-0.70]$ & $\rightarrow-$ & & \\
\hline McHardy 2020 & 3.3 & 3 & 92 & 3.3 & 2.9 & 90 & $35.8 \%$ & $0.00[-0.29,0.29]$ & & - & \\
\hline Sakae 2017 & 0.55 & 0.82 & 20 & 1.6 & 1.31 & 20 & $30.2 \%$ & $-0.94[-1.60,-0.28]$ & $\longrightarrow-$ & & \\
\hline Total $(95 \% \mathrm{Cl})$ & & & 162 & & & 159 & $100.0 \%$ & $-0.67[-1.48,0.15]$ & & & \\
\hline $\begin{array}{l}\text { Heterogeneity: Tau }= \\
\text { Test for overall effect: }\end{array}$ & $\begin{array}{l}=0.46 ; \mathrm{Cr} \\
Z=1.60\end{array}$ & $\begin{array}{l}i^{2}=20 . \\
(P=0.1\end{array}$ & 99, df $=$ & $2(P<0$. & $0001) ; 1$ & $=90 \%$ & & & $\begin{array}{cc}-4 & -2 \\
& \text { Favours [experimental] }\end{array}$ & 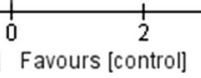 & 4 \\
\hline
\end{tabular}

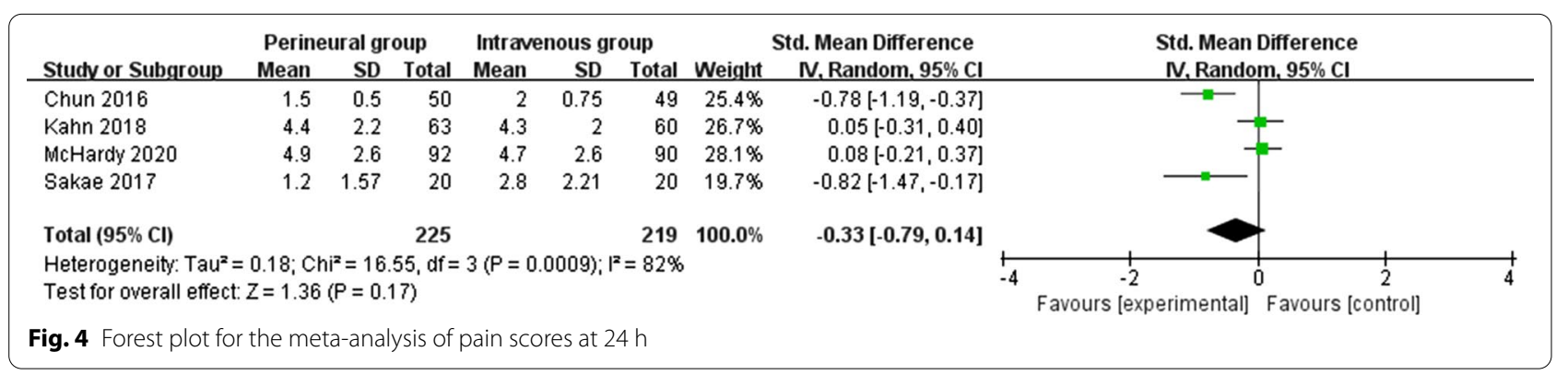

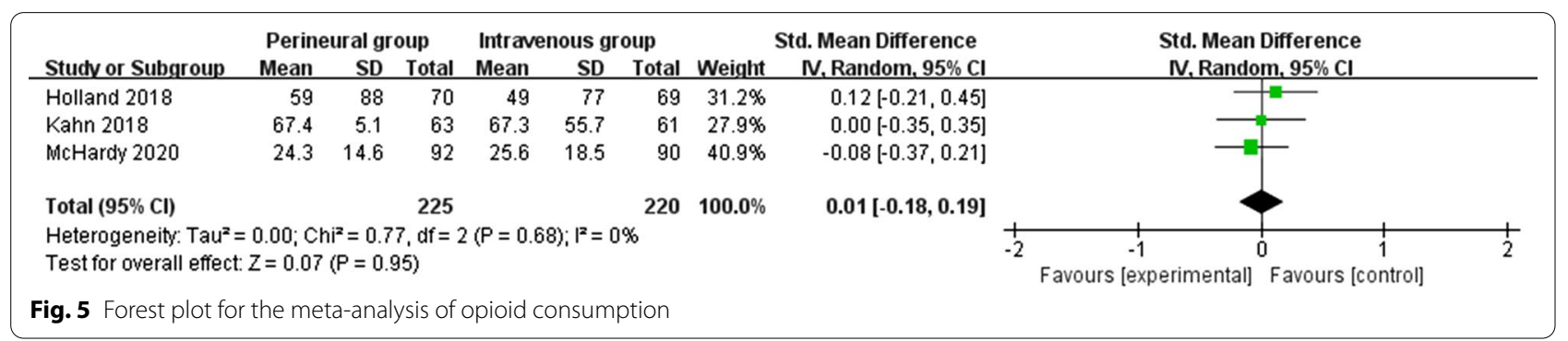

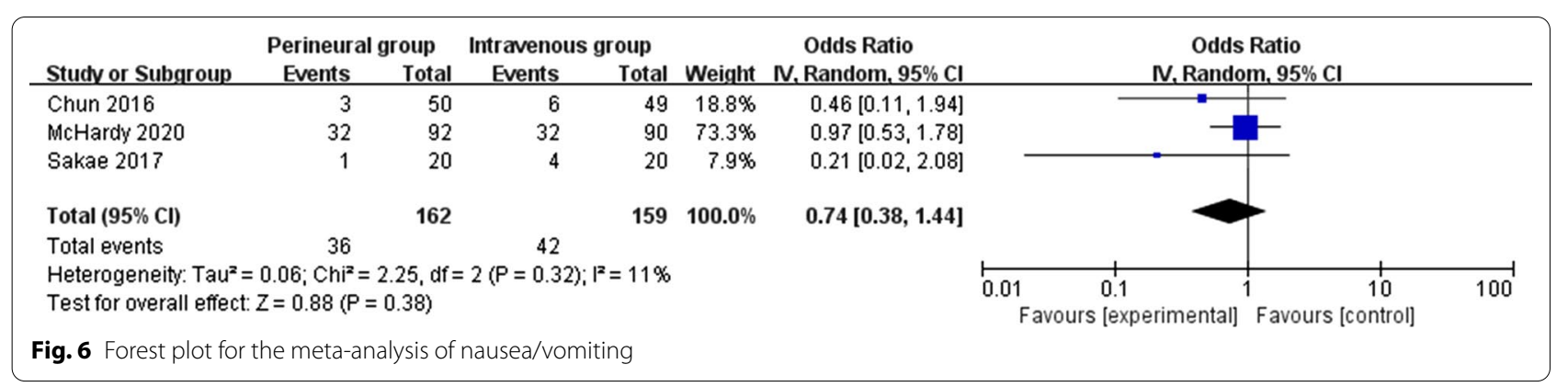


arthroscopy, our meta-analysis included five RCTs and revealed that perineural and intravenous dexamethasone resulted in comparable block duration, pain control and opioid consumption when in conjunction with local analgesics for shoulder arthroscopy. Dexamethasone is found to reduce ectopic neuronal discharge and inhibit potassium channel-mediated discharge of nociceptive C-fibers. Additionally, dexamethasone supplementation can provide superior analgesia in the context of peripheral nerve block through systemic anti-inflammatory effects $[10,35]$.

As shown in Fig. 3, considerable clinical heterogeneity is observed, and we searched for potential sources of heterogeneity via omitting one study in turn. After excluding the study conducted by McHardy et al. [10], we found that no heterogeneity remained and perineural dexamethasone resulted in lower pain scores at $12 \mathrm{~h}$ than intravenous dexamethasone $(\mathrm{SMD}=-1.07 ; 95 \% \mathrm{CI}$ -1.43 to $-0.71 ; \mathrm{P}<0.00001)$. McHardy et al. reported the perineural dexamethasone at the concentration of $0.667 \mathrm{mg} / \mathrm{ml}$ [10], while other two studies reported the perineural dexamethasone at the concentration of 0.190 and $0.417 \mathrm{mg} / \mathrm{ml}[19,20]$. In addition, in Fig. 4, Kahn et al. reported perineural dexamethasone at the concentration of $1 \mathrm{mg} / \mathrm{ml}$ [12], and perineural dexamethasone at the concentration of $1 \mathrm{mg} / \mathrm{ml}$ and $0.667 \mathrm{mg} / \mathrm{ml}$ can obtain the comparable analgesic efficacy than intravenous dexamethasone. These indicated that the lower concentration of perineural dexamethasone $(\leq 0.417 \mathrm{mg} /$ $\mathrm{ml}$ ) produced substantially lower analgesic efficacy than intravenous dexamethasone for shoulder arthroscopy, and higher concentration of perineural dexamethasone $(\geq 0.667 \mathrm{mg} / \mathrm{ml})$ and intravenous dexamethasone had comparable analgesic efficacy, suggesting that concentrations of perineural dexamethasone were crucial for the analgesic efficacy of interscalene block in patients with shoulder arthroscopy.

In addition, the incidence of nausea/vomiting was similar between two groups based on our results. This metaanalysis also has several limitations. Firstly, our analysis is based on five RCTs, and two of them have a relatively small sample size $(\mathrm{n}<100)$. Overestimation of the treatment effect is more likely in smaller trials compared with larger samples. Next, different concentrations and combination methods of dexamethasone may produce some bias. Finally, it is not feasible to perform the metaanalysis of some important index such as discharge time and time to first analgesic requirement based on current RCTs.

\section{Conclusions}

Perineural and intravenous dexamethasone showed similar efficacy for block duration after shoulder arthroscopy.

\section{Abbreviations}

RCTs: Randomized controlled trials; MDs: Mean differences; Cls: Confidence intervals; RRs: Risk ratios.

\section{Acknowledgements}

None.

\section{Authors' contributions}

$\mathrm{LH}$ and PL conducted the design, study planning, data analysis and data interpretation. $\mathrm{LH}, \mathrm{PL}, \mathrm{HZ}$ and $\mathrm{ZZ}$ wrote and revised the article. All authors read and approved the final manuscript.

\section{Funding}

Not applicable.

Availability of data and materials

Not applicable.

\section{Declarations}

Ethical approval and consent to participate

Not applicable.

\section{Consent for publication}

Not applicable.

\section{Competing interests}

The authors declare no competing interests.

\section{Author details}

'Department of Hand Surgery, Xi'an Honghui Hospital, Xi'an Jiaotong University Health Science Center, Xi'an 710054, Shaanxi, China. ${ }^{2}$ Department of Orthopaedic Oncology, Xi'an Honghui Hospital, Xi'an Jiaotong University Health Science Center, Xi'an 710054, Shaanxi, China. ${ }^{3}$ Sports Medicine Center, Xi'an Honghui Hospital, Xi'an Jiaotong University Health Science Center, No. 555 Youyidong Street, Beilin District, Xi'an 710054, Shaanxi, China.

Received: 13 June 2021 Accepted: 21 January 2022

Published online: 17 February 2022

\section{References}

1. Cabaton J, Nové-Josserand L, Mercadal L, Vaudelin T. Analgesic efficacy of ultrasound-guided interscalene block vs. supraclavicular block for ambulatory arthroscopic rotator cuff repair: a randomised noninferiority study. Eur J Anaesthesiol. 2019;36(10):778-86.

2. Burkhart SS. Shoulder arthroscopy: a bridge from the past to the future. J Shoulder Elbow Surg. 2020;29(8):e287-96.

3. Warrender WJ, Syed UAM, Hammoud S, Emper W, Ciccotti MG, Abboud JA, Freedman KB. Pain management after outpatient shoulder arthroscopy: a systematic review of randomized controlled trials. Am J Sports Med. 2017:45(7):1676-86.

4. Uquillas CA, Capogna BM, Rossy WH, Mahure SA, Rokito AS. Postoperative pain control after arthroscopic rotator cuff repair. J Shoulder Elbow Surg. 2016;25(7):1204-13.

5. Fredrickson MJ, Krishnan S, Chen CY. Postoperative analgesia for shoulder surgery: a critical appraisal and review of current techniques. Anaesthesia. 2010;65(6):608-24.

6. Lee JH, Cho SH, Kim SH, Chae WS, Jin HC, Lee JS, Kim YI. Can J Anaesth = Journal canadien d'anesthesie. 2011;58(11):1001-6.

7. Zhai W, Wang X, Rong Y, Li M, Wang H. Effects of a fixed low-dose ropivacaine with different volume and concentrations on interscalene brachial plexus block: a randomized controlled trial. BMC Anesthesiol. 2016;16(1):80.

8. Sinha SK, Abrams JH, Barnett JT, Muller JG, Lahiri B, Bernstein BA, Weller RS. Decreasing the local anesthetic volume from 20 to $10 \mathrm{~mL}$ for ultrasound-guided interscalene block at the cricoid level does not reduce 
the incidence of hemidiaphragmatic paresis. Reg Anesth Pain Med. 2011;36(1):17-20.

9. Abdallah FW, Halpern SH, Aoyama K, Brull R. Will the real benefits of single-shot interscalene block please stand up? A systematic review and meta-analysis. Anesth Analg. 2015;120(5):1114-29.

10. McHardy PG, Singer O, Awad IT, Safa B, Henry PDG, Kiss A, Au SK, Kaustov $L$, Choi S. Comparison of the effects of perineural or intravenous dexamethasone on low volume interscalene brachial plexus block: a randomised equivalence trial. Br J Anaesth. 2020;124(1):84-91.

11. Albrecht E, Kern C, Kirkham KR. A systematic review and meta-analysis of perineural dexamethasone for peripheral nerve blocks. Anaesthesia. 2015;70(1):71-83.

12. Kahn RL, Cheng J, Gadulov Y, Fields KG, YaDeau JT, Gulotta LV. Perineural low-dose dexamethasone prolongs interscalene block analgesia with bupivacaine compared with systemic dexamethasone: a randomized trial. Reg Anesth Pain Med. 2018;43(6):572-9.

13. Holland D, Amadeo RJJ, Wolfe S, Girling L, Funk F, Collister M, Czaplinski E, Ferguson C, Leiter J, Old J, MacDonald P, Dufault B, Mutter TC. Effect of dexamethasone dose and route on the duration of interscalene brachial plexus block for outpatient arthroscopic shoulder surgery: a randomized controlled trial. Can J Anaesth $=$ Journal canadien d'anesthesie. 2018;65(1):34-45.

14. Moher D, Liberati A, Tetzlaff J, Altman DG, Group P. Preferred reporting items for systematic reviews and meta-analyses: the PRISMA statement. J Clin Epidemiol. 2009;62(10):1006-12.

15. Zhao J, Huang W, Zhang S, Xu J, Xue W, He B, Zhang Y. Efficacy of glutathione for patients with cystic fibrosis: a meta-analysis of randomizedcontrolled studies. Am J Rhinol Allergy. 2019. https://doi.org/10.1177/ 1945892419878315.

16. Jadad AR, Moore RA, Carroll D, Jenkinson C, Reynolds DJM, Gavaghan DJ, McQuay HJ. Assessing the quality of reports of randomized clinical trials: is blinding necessary? Control Clin Trials. 1996;17(1):1-12.

17. Kjaergard LL, Villumsen J, Gluud C. Reported methodologic quality and discrepancies between large and small randomized trials in meta-analyses. Ann Intern Med. 2001;135(11):982-9.

18. Higgins JP, Thompson SG. Quantifying heterogeneity in a meta-analysis. Stat Med. 2002;21(11):1539-58.

19. Sakae TM, Marchioro P, Schuelter-Trevisol F, Trevisol DJ. Dexamethasone as a ropivacaine adjuvant for ultrasound-guided interscalene brachial plexus block: a randomized, double-blinded clinical trial. J Clin Anesth. 2017;38:133-6.

20. Chun EH, Kim YJ, Woo JH. Which is your choice for prolonging the analgesic duration of single-shot interscalene brachial blocks for arthroscopic shoulder surgery? Intravenous dexamethasone $5 \mathrm{mg}$ vs. perineural dexamethasone $5 \mathrm{mg}$ randomized, controlled, clinical trial. Medicine. 2016;95(23):e3828.

21. Botser IB, Smith TW Jr, Nasser R, Domb BG. Open surgical dislocation versus arthroscopy for femoroacetabular impingement: a comparison of clinical outcomes. Arthroscopy. 2011;27(2):270-8.

22. Li C, Qu J. Efficacy of dexmedetomidine for pain management in knee arthroscopy: a systematic review and meta-analysis. Medicine. 2017;96(43):e7938.

23. Tepolt FA, Bido J, Burgess S, Micheli $\sqcup$, Kocher MS. Opioid overprescription after knee arthroscopy and related surgery in adolescents and young adults. Arthroscopy. 2018. https://doi.org/10.1016/j.arthro.2018.07.021.

24. Tong D, Chung F. Postoperative pain control in ambulatory surgery. Surg Clin N Am. 1999;79(2):401-30.

25. Chen X, Mou X, He Z, Zhu Y. The effect of midazolam on pain control after knee arthroscopy: a systematic review and meta-analysis. J Orthop Surg Res. 2017;12(1):179.

26. Nicholson T, Maltenfort M, Getz C, Lazarus M, Williams G, Namdari S. Multimodal pain management protocol versus patient controlled narcotic analgesia for postoperative pain control after shoulder arthroplasty. Arch Bone Joint Surg. 2018;6(3):196.

27. Jung HS, Seo KH, Kang JH, Jeong J-Y, Kim Y-S, Han N-R. Optimal dose of perineural dexmedetomidine for interscalene brachial plexus block to control postoperative pain in patients undergoing arthroscopic shoulder surgery: a prospective, double-blind, randomized controlled study. Medicine. 2018;97(16):e0440.
28. Calvo E, Torres MD, Morcillo D, Leal V. Rotator cuff repair is more painful than other arthroscopic shoulder procedures. Arch Orthop Trauma Surg. 2019;139(5):669-74.

29. Ullah H, Samad K, Khan FA. Continuous interscalene brachial plexus block versus parenteral analgesia for postoperative pain relief after major shoulder surgery. Cochrane Database Syst Rev. 2014;2014(2):Cd007080.

30. Hortense A, Perez MV, Amaral JL, Oshiro AC, Rossetti HB. Interscalene brachial plexus block. Effects on pulmonary function. Rev Bras Anestesiol. 2010;60(2):130-7.

31. Stundner O, Meissnitzer M, Brummett CM, Moser S, Forstner R, Koköfer A, Danninger T, Gerner P, Kirchmair L, Fritsch G. Comparison of tissue distribution, phrenic nerve involvement, and epidural spread in standard- vs low-volume ultrasound-guided interscalene plexus block using contrast magnetic resonance imaging: a randomized, controlled trial. $\mathrm{Br} J$ Anaesth. 2016;116(3):405-12.

32. Desmet M, Braems H, Reynvoet M, Plasschaert S, Van Cauwelaert J, Pottel H, Carlier S, Missant C, Van de Velde M. IV and perineural dexamethasone are equivalent in increasing the analgesic duration of a single-shot interscalene block with ropivacaine for shoulder surgery: a prospective, randomized, placebo-controlled study. Br J Anaesth. 2013;111(3):445-52.

33. Abdallah FW, Johnson J, Chan V, Murgatroyd H, Ghafari M, Ami N, Jin R, Brull R. Intravenous dexamethasone and perineural dexamethasone similarly prolong the duration of analgesia after supraclavicular brachial plexus block: a randomized, triple-arm, double-blind, placebo-controlled trial. Reg Anesth Pain Med. 2015;40(2):125-32.

34. Rosenfeld DM, Ivancic MG, Hattrup SJ, Renfree KJ, Watkins AR, Hentz JG, Gorlin AW, Spiro JA, Trentman TL. Perineural versus intravenous dexamethasone as adjuncts to local anaesthetic brachial plexus block for shoulder surgery. Anaesthesia. 2016;71(4):380-8.

35. Attardi B, Takimoto K, Gealy R, Severns C, Levitan ES. Glucocorticoid induced up-regulation of a pituitary $\mathrm{K}+$ channel mRNA in vitro and in vivo. Receptors Channels. 1993;1 (4):287-93.

\section{Publisher's Note}

Springer Nature remains neutral with regard to jurisdictional claims in published maps and institutional affiliations.

Ready to submit your research? Choose BMC and benefit from:

- fast, convenient online submission

- thorough peer review by experienced researchers in your field

- rapid publication on acceptance

- support for research data, including large and complex data types

- gold Open Access which fosters wider collaboration and increased citations

- maximum visibility for your research: over 100M website views per year

At BMC, research is always in progress.

Learn more biomedcentral.com/submissions 